\title{
Contribution of adenoviral-mediated superoxide dismutase gene transfer to the reduction in nitric oxide-induced cytotoxicity on human islets and INS-1 insulin-secreting cells
}

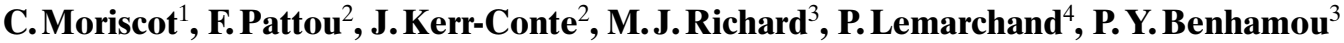 \\ ${ }^{1}$ Institute of Structural Biology, Grenoble, France \\ ${ }^{2}$ UPRES 1048, Cell Culture Laboratory, University Hospital, Lille, France \\ ${ }^{3}$ Department of Endocrinology, University Hospital, Grenoble, France \\ ${ }^{4}$ INSERM U25, Necker School of Medicine, Paris, France
}

\section{Abstract}

Aims/hypothesis. Vulnerability of pancreatic islets to oxygen free radicals and nitric oxide contributes to islet transplantation obstacles. This susceptibility can be linked to the low expression levels of antioxidant enzymes in islets. Our aim was to investigate the effect of overexpressing $\mathrm{Cu} / \mathrm{Zn}$ superoxide dismutase in human islets through a simple procedure on the cytotoxic effects of two nitric oxide donors: 3-morpholinosydnonimine (SIN-1) and S-Nitroso- $N$-acetyl-D,Lpenicillamine (SNAP).

Methods. Cultured human islets and INS-1 rat-derived insulin-secreting cells were transfected by an E1-deleted adenovirus carrying $\mathrm{Cu} / \mathrm{Zn}$ SOD cDNA under the control of a cytomegalovirus (CMV) promoter (AdSOD). The viability of the cells was tested by the WST-1 assay (Roche, Indianapolis, Ind., USA).

Results. The AdSOD procedure allowed SOD activity to increase by twofold to threefold for 2 to 8 days following transfection. Adenovirus-driven SOD overexpression was associated with a significant reduction of SIN-1-induced cytotoxicity on human islets $(69.9 \pm 10.5 \%$ protection at $200 \mu \mathrm{mol} / \mathrm{l}$ and $40.5 \pm$ $8.9 \%$ protection at $400 \mu \mathrm{mol} / \mathrm{l}$ ) and INS-1 cells $(82.2 \pm 8.8 \%$ protection at $200 \mu \mathrm{mol} / 1$ and $31.1 \pm$ $5.8 \%$ protection at $400 \mu \mathrm{mol} / 1)$. Protection against increasing doses of SNAP was AdSOD dose-dependent. Transfected islets released significantly more insulin than control islets in glucose-theophyllinstimulated conditions, without or following exposure to SNAP.

Conclusions/interpretation. We thus established that adenoviral-induced overexpression of $\mathrm{Cu} / \mathrm{Zn} \mathrm{SOD}$ can be beneficial to human islet endocrine function and resistance to nitric oxide cytotoxicity. These data could be relevant for the development of new strategies aimed at preventing NO-induced beta-cell damage in an islet transplantation setting. [Diabetologia (2000) 43: 625-631]

Keywords Islet transplantation, nitric oxide, oxidant stress, superoxide dismutase, reactive oxygen species, adenovirus, gene transfer.
Received: 9 September 1999 and in revised form: 5 February 2000

Corresponding author: Dr P. Y. Benhamou, Department of Endocrinology, CHU, BP 217X, 38043 Grenoble, France

Abbreviations: AdSOD, Adenovirus-driven superoxide dismutase; IEQ, equivalent number of islets; MOI, multiplicity of infection; NO, nitric oxide; pfu, plaque-forming units; ROS, reactive oxygen species; SIN-1, 3-Morpholino sydnonimine. $\mathrm{HCl}$; SNAP, S-Nitroso- $N$-acetyl-D,L-penicillamine; SOD, superoxide dismutase.
It has been established from numerous studies that oxygen and nitrogen free radicals can contribute to the islet beta-cell destruction in Type I (insulin-dependent) diabetes mellitus models [1-2]. The deleterious actions of activated mononuclear cells could be mediated by cytokines through an increase in the intracellular generation of superoxide anions, nitric oxide (NO) and peroxynitrite [3-5]. Islet beta cells appear to have an exquisite sensitivity to these radicals because of constitutively low expression of antioxidant enzymes [6-7]. Several reports explained the rationale of increasing antioxidant enzyme expression 
in beta cells to enhance their resistance to a cytotoxic challenge [8]. Most authors focused on stable overexpression of these enzymes, using stable gene transfer technologies in beta-cell lines, or transgenic approaches [9-11]. Concordant data were reported with catalase or glutathione peroxidase as both enzymes exhibited a cytoprotective effect on beta cells [12-13]. Conversely, superoxide dismutase (SOD) overexpression so far generated conflicting results. The question addressed in our study is the relevance of modulating antioxidant enzymes in an islet transplantation setting. We therefore transfected human islets with recombinant adenovirus vectors, which are potential candidates for gene transfer trials in humans. We have established previously that adenoviral-driven catalase overexpression reduced the cytotoxicity of superoxide donors on human, porcine and rat islets [14]. This time we examined the effect of adenoviral-mediated SOD gene transfer in human islets and rat-derived insulin-secreting INS-1 cells on the cytotoxicity induced by nitric oxide donors.

\section{Material and methods}

Pancreatic human islets and INS-1 cells. Human pancreata were procured from heart-beating cadaveric donors according to the French regulations (1994 Bioethic Act allowing procurement with presumed consent). Islets were isolated as reported previously [15] in the Cell Culture Core Laboratory at the University Hospital of Lille. Within $8 \mathrm{~h}$ of hypothermic conservation after procurement, the pancreas was distended by intraductal injection of an enzymatic solution (Liberase, Roche Diagnostics, Meylan, France) and digested at $37^{\circ} \mathrm{C}$ for 20 to $30 \mathrm{~min}$ according to the automated method of Ricordi. Islets were purified by isopycnic centrifugation in a discontinuous gradient (Histopaque, Sigma Chimie, Saint Quentin Fallavier, France) with a cell separator (COBE 2991, Cobe, Lakewood, Colo., USA). After overnight culture at $27^{\circ} \mathrm{C}$ in CMRL 1066 (Gibco BRL, Paisley, Scotland) containing 2\% Ultroser (Gibco), and quality control, islets were shipped within $24 \mathrm{~h}$ to Grenoble by express mail in an excess of culture media at room temperature. The viability of islets was confirmed upon arrival for each preparation by vital staining using fluorescent probes [15] and functionality as described below. Upon arrival, islets were cultured in plastic Petri dishes at $37^{\circ} \mathrm{C}$ in $95 \%$ air and $5 \% \mathrm{CO}_{2}$. Culture medium was RPMI 1640 , containing $10 \%$ fetal bovine serum (FBS), $25 \mathrm{mmol} / \mathrm{l}$ HEPES, $24 \mathrm{mmol} / \mathrm{l}$ sodium bicarbonate, and penicillin-streptomycin-amphotericin B solution. Islet number was determined on a sample after dithizone staining and expressed as equivalent number of islets (IEQ: number of islets if all were $150 \mu \mathrm{m}$ in diameter). Preparations used in this study were obtained from 9 donors (mean age $27 \pm 3$ years) and yielded an average of $2226 \pm 670 \mathrm{IEQ} / \mathrm{g}$ and over $70 \%$ purity. Rat insulinoma cell line INS-1 (courtesy of W.P. Pralong, Lausanne, Switzerland) were cultured in RPMI 1640 medium as described previously [16].

Adenoviral vectors. We used a E1-deleted, replication-deficient recombinant adenovirus containing human $\mathrm{Cu} / \mathrm{Zn}$ superoxide dismutase cDNA under the control of a cytomegalovirus (CMV) promoter, AdSOD, constructed as described previous- ly [17]. Two negative controls consisted of a similar adenovirus containing no cDNA (AdNull) or the LacZ reporter gene encoding for $\beta$-galactosidase (AdLaZ). The recombinant adenovirus were propagated in 293 cells and were purified by $\mathrm{CsCl}$ density purification. The preparations were dialysed and stored in the dialysis buffer $(10 \mathrm{mmol} / 1$ TRIS-Cl $\mathrm{pH} 7.8$, $15 \mathrm{mmol} / \mathrm{l} \mathrm{NaCl}, 10 \mathrm{mmol} / 1 \mathrm{MgCl}_{2}, 10 \%$ glycerol) at $-70^{\circ} \mathrm{C}$ until use. The titre of each viral stock was determined by plaque assay on 293 cells, and the titres consistently ranged between $1-2 \times 10^{11}$ plaque-forming units $(\mathrm{pfu}) / \mathrm{ml}$. Absence of replication-competent particles in adenovirus preparations was checked by PCR using primers specific for the AdE1A region. The concentration of recombinant adenovirus was quantified also by optical absorbance, and the ratio of particles to pfu consistently ranged between 50 and 80 [17].

Transfection of islets. Islets in suspension in $50 \mathrm{ml}$ polypropylene tubes were washed once with culture medium and resuspended at a concentration of 4000 IEQ in $0.5 \mathrm{ml}$ culture medium. Adenovirus was added at different multiplicity of infection ratios (MOI) as stated below, and islets were incubated at $37^{\circ} \mathrm{C}$ in $95 \%$ air and $5 \% \mathrm{CO}_{2}$ for $1 \mathrm{~h}$, washed once with culture medium, and cultured in multiwell plates at a density of 20 islets per well. We cultured INS- 1 cells in 96-well plates at an initial density of $3 \times 10^{4}$ cells per well for $48 \mathrm{~h}$, then exposed them to adenovirus in $100 \mu \mathrm{l}$ culture medium at different MOIs for $1 \mathrm{~h}$ and washed.

Enzymatic activities of SOD. Islets were pelleted by centrifugation and lysed by five freezing and thawing cycles in hypotonic $20 \mathrm{mmol} / \mathrm{l}$ TRIS-HCl buffer. Enzyme activites were determined in the supernatant obtained after centrifugation (10 $\mathrm{min}, 4000 \mathrm{rev} / \mathrm{min}, 4^{\circ} \mathrm{C}$ ) of the islet homogenate. Total superoxide dismutase activity (MnSOD and $\mathrm{Cu} / \mathrm{ZnSOD}$ ) was measured by monitoring the auto-oxidation of pyrogallol according to the procedure of Marklund and Marklund [18]. One unit of SOD activity was defined as the amount of enzyme required to inhibit the rate of pyrogallol auto-oxidation by $50 \%$. The specific $\mathrm{Cu} / \mathrm{ZnSOD}$ inhibition by KCN ( $9 \mathrm{mmol} / \mathrm{l} \mathrm{fi-}$ nal concentration) allows the MnSOD determination in the same conditions. All results were expressed relative to islet lysate protein content. Data were established from triplicate samples and from four different batches of islets to control for interindividual variability.

$X$-gal staining of transfected islets. Islets were washed twice with $\mathrm{PBS}$ and fixed in PBS containing $0.2 \%$ glutaraldehyde and $2 \%$ formaldehyde $(\mathrm{pH} 7.2)$ for $10 \mathrm{~min}$ at $4{ }^{\circ} \mathrm{C}$. After one wash with PBS, islets were incubated at $30^{\circ} \mathrm{C}$ for $3-12 \mathrm{~h}$ with the staining solution $(5 \mathrm{mmol} / \mathrm{l}$ potassium ferrocyanide, $5 \mathrm{mmol} / \mathrm{l}$ potassium ferricyanide, $2 \mathrm{mmol} / \mathrm{l} \mathrm{MgCl}$ and $1 \mathrm{mg} / \mathrm{ml}$ $\mathrm{X}$-gal in DMSO). Islets staining deep blue were regarded as positive and counted, while nonexpressing islets appear clear. A further assessment of gene transfer efficiency was made on islets that were dispersed in single cells following X-gal staining. Single islet cell suspensions were obtained by brief trypsin digestion $(0.125 \mathrm{mg} / \mathrm{ml}$ with $0.1 \mathrm{mmol} / \mathrm{l}$ EDTA (Gibco, Grand Island, N. Y., USA) [19].

Cytotoxic challenge. We used two sources of nitric oxide in our study [20]. SNAP (S-Nitroso- $N$-acetyl-D,L-penicillamine) spontaneously decomposes to release nitric oxide. Both NO and superoxide are generated by SIN-1 (3-Morpholinosydnonimine. $\mathrm{HCl}$ ) in an equimolar manner resulting in the formation of peroxynitrite. In both cytotoxic challenges, islets or cells were stressed $72 \mathrm{~h}$ after transfection with AdSOD. We dissolved SIN-1 or SNAP (Alexis, San Diego, Calif., 
USA) before use in RPMI culture medium. These reagents were added to the wells containing islets (96-well plates, 20 islets per well) or INS-1 cells in $200 \mu \mathrm{l}$ at final concentrations ranging from 100 to $1000 \mu \mathrm{mol} / 1$. Control wells received medium alone. Stressed islets were then cultured for $16 \mathrm{~h}$ before viability tests.

In vitro islet viability. Islet mitochondrial activity was assessed by WST-1 assay (Roche, Indianapolis, Ind., USA). This colorimetric assay is derived from the MTT test that was previously established as a valid method for islet viability assessment [21]. It is based on the cleavage of a tetrazolium salt (4-[3-(4Iodophenyl)-2-(4-nitrophenyl)-2H-5-tetrazolio]-1,3-benzene disulfonate) to formazan by the mitochondrial succinate-tetrazolium reductase. The formazan dye produced by viable cells is quantified in a multiwell spectrophotometer by measurement of the optical density (OD) at $440 \mathrm{~nm}$. Each experiment was carried out with 12 wells per experimental group. Cytotoxicity of NO donors and protective activity of AdSOD (percentage of protection) were defined according to the following formula:

Cytotoxicity on control islets $\mathrm{C}=\left(\mathrm{OD}_{\mathrm{C}}-\mathrm{OD}_{\mathrm{CS}} / \mathrm{OD}_{\mathrm{C}}\right) \times 100$ where $\mathrm{OD}_{\mathrm{C}}=\mathrm{OD}$ of control islets and $\mathrm{OD}_{\mathrm{CS}}=\mathrm{OD}$ of control islets exposed to cytotoxic stress

Cytotoxicity on transfected islets $\mathrm{T}=\left(\mathrm{OD}_{\mathrm{T}}-\mathrm{OD}_{\mathrm{TS}} / \mathrm{OD}_{\mathrm{T}}\right) \times 100$ where $\mathrm{OD}_{\mathrm{T}}=\mathrm{OD}$ of transfected islets and $\mathrm{OD}_{\mathrm{TS}}=\mathrm{OD}$ of transfected islets exposed to cytotoxic stress

Percentage of protection $=(\mathrm{C}-\mathrm{T} / \mathrm{C}) \times 100$

In vitro islet functionality. Glucose-stimulated insulin secretion was determined by static incubation. Aliquots of 200 islets were plated in triplicate on $3 \mu \mathrm{m}$ Millicell inserts (Millipore, Bedford, Mass., USA) in a 24-well plate and consecutively stimulated for four different 1 -h periods in Krebs buffer containing $0.5 \% \mathrm{BSA}$ and $3.3 \mathrm{mmol} / 1$ glucose (period one and two), $27.5 \mathrm{mmol} / \mathrm{l}$ glucose $+10 \mathrm{mmol} / \mathrm{l}$ theophylline (period three), $3.3 \mathrm{mmol} / \mathrm{l}$ glucose (period four). Medium samples were frozen at $-20^{\circ} \mathrm{C}$ for further insulin determination by RIA (CIS bio, Gif-sur-Yvette, France). A stimulation index was obtained as the ratio of insulin released during period three to the average of insulin released during periods two and four. Tissue insulin content was determined on triplicate samples of 200 islets $48 \mathrm{~h}$ following transfection with AdSOD at an MOI of 25:1. Acid alcohol was added to the cells, vortexed and incubated for $18 \mathrm{~h}$ at $4{ }^{\circ} \mathrm{C}$ to extract insulin.

Statistical analysis. Comparisons of cytotoxicity levels between control and AdSOD-treated islets were done with analysis of variance completed by Tukey-Kramer's test. In addition, significance was checked with a nonparametric test (KruskalWallis). Data are shown as means \pm SEM. Significance was set at $p<0.05$.

\section{Results}

Enzymatic activities of baseline SOD. Activities were measured after overnight culture from triplicate samples of individual preparations of human islets $(n=4)$ and INS-1 cells $(n=3)$. As shown in Table 1 , total SODs activities showed a threefold higher level in human islets $(31.2 \pm 4.9 \mathrm{U} / \mathrm{mg}$, range $12.5-47.2, \mathrm{CV}$ $41.4 \%)$ than in INS-1 cells $(8.7 \pm 0.4 \mathrm{U} / \mathrm{mg}$, range
Table 1. Baseline superoxide dismutase activities in human islets and INS- 1 cells

\begin{tabular}{lll}
\hline $\begin{array}{l}\text { SOD activity } \\
\text { (U/mg protein) }\end{array}$ & INS-1 cells & Human islets \\
\hline Total SOD & $8.7 \pm 0.4$ & $31.2 \pm 4.9$ \\
MnSOD & $3.1 \pm 0.8$ & $20.9 \pm 3.5$ \\
Cu/ZnSOD & $5.6 \pm 0.9$ & $10.2 \pm 1.9$ \\
\hline
\end{tabular}

${ }^{a}$ Results were obtained from triplicate samples taken from different preparations (human: $n=4$; INS-1: $n=3$ ). Table shows means \pm SEM from pooled data. Statistical significance was: $p<0.05$ human vs INS-1

6.7-10.7, CV $15.6 \%, p<0.05$ vs human). Human islet SOD activity was predominantly MnSOD $(65.6 \pm 3.4 \%)$ as opposed to INS-1 cells which expressed more $\mathrm{Cu} / \mathrm{ZnSOD}(63.9 \pm 2.5 \%)$ (Table 1$)$.

Efficiency of transfection. Total SODs and $\mathrm{Cu} / \mathrm{Zn}$ SOD activites were raised twofold to threefold following adenovirus-mediated gene transfer in human islets and INS-1 cells, using an MOI of 10 to $25 \mathrm{pfu} /$ islet cell, and overexpression was maintained for 8 days, the duration of the monitoring period. Figure 1 shows data established with one human islet preparation at an MOI of 25:1 (baseline SODs 14.5 \pm 2.0

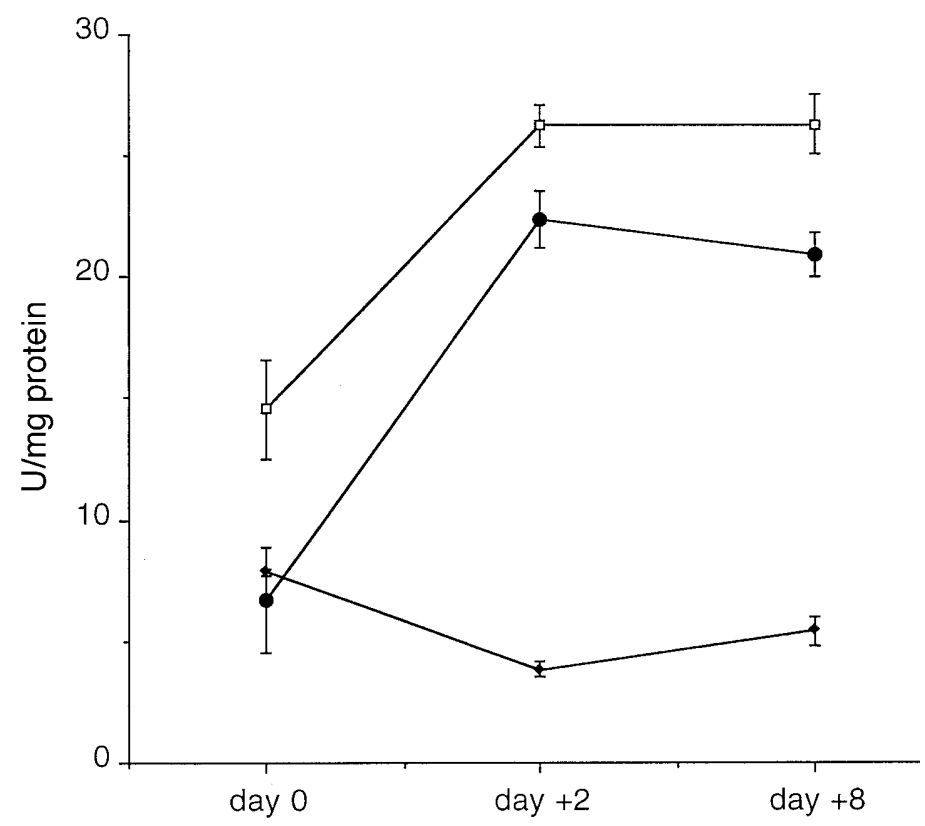

Fig. 1. SOD activity in human islets 2 and 8 days after gene transfer using AdSOD at MOI of 25

Total SODs and $\mathrm{Cu} / \mathrm{ZnSOD}$ activities achieved by AdSOD transfection were twofold to threefold higher than in control islets and stable throughout the monitoring period of 8 days. Data obtained from one pancreas are shown here (means \pm SEM of triplicate samples). Average total SODs on day 0,2 and 8 following transfection of three human islet preparations with MOI 25 were $18.6 \pm 4.3,44.5 \pm 7.5,42.1 \pm 1.4 \mathrm{U} / \mathrm{mg}$, respectively $(p<0.05$ control vs AdSOD). $\square \square-$ total SODs, $\longrightarrow \mathrm{MnSOD}, \longrightarrow \mathrm{Cu} / \mathrm{ZnSOD}$ 


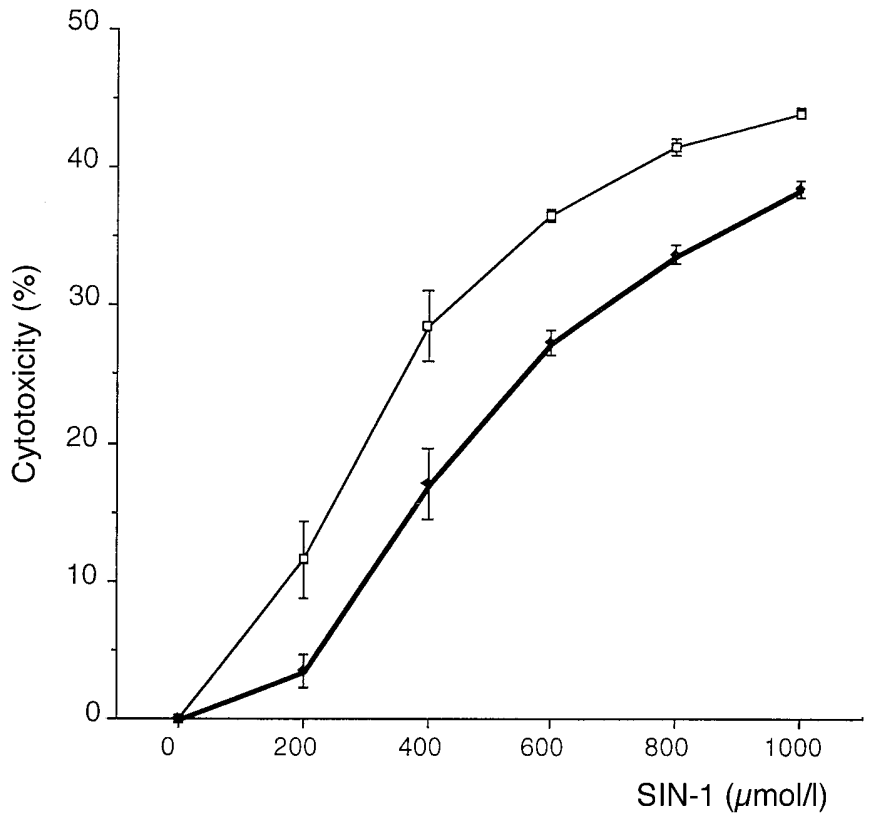

Fig. 2. Reduction of SIN-1-induced cytotoxicity on human islets by AdSOD

Human islets cell were transfected at MOI 10, incubated at 20 islets per well for $72 \mathrm{~h}$, stressed by increasing doses of SIN-1, and assessed for viability by WST-1 assay $16 \mathrm{~h}$ later. Data show means \pm SEM of 12 wells per experimental group. Similar data were obtained from INS-1 cells. Results of a typical experiment are shown here while protection indices computed from three human islet or INS-1 cell preparations, are summarised in Table 2. $\square \square-$ control, $\longrightarrow$ AdSOD

$\mathrm{U} / \mathrm{mg}$; transfected $26.2 \pm 0.8 \mathrm{U} / \mathrm{mg}$ on day $2,26.3 \pm 1.2$ $\mathrm{U} / \mathrm{mg}$ on day $8-$ baseline $\mathrm{Cu} / \mathrm{ZnSOD} 6.70 \pm 2.2$ $\mathrm{U} / \mathrm{mg}$, transfected $22.4 \pm 1.2 \mathrm{U} / \mathrm{mg}$ on day $2,20.9 \pm 0.9$ $\mathrm{U} / \mathrm{mg}$ on day 8) (Fig.1).

Patterns of transfection. Following X-gal staining of AdLacZ transfected islets, all islets scored positive, showing blue cells in the islet cluster. There was, however, great variability in the intensity of staining, reflecting differences in the number of transfected cells per islet. When transfected islets were dispersed into single cells, 34 to $45 \%$ of cells stained blue with Xgal at an MOI of 10:1 to 25:1, respectively.
Efficiency of SOD gene transfer on cellular viability. Exposure of human islets to increasing doses of SIN-1 resulted in a dose-dependent cytotoxic effect, shown by WST-1 assay, as illustrated in Fig. 2 and summarised in Table 2. Doses of SIN-1 of 200 to $800 \mu \mathrm{mol} / \mathrm{l}$ applied to control or AdSOD-transfected islets resulted in cytotoxicity $(p<0.05$ control vs transfected islets at every SIN-1 dose). Similar data were obtained from INS-1 cells (Table 2). Thus, in both cellular models, adenovirus-driven SOD overexpression was associated with a significant reduction of SIN-1 induced cytotoxicity, within a window of 200 to $400 \mu \mathrm{mol} / \mathrm{l} \mathrm{SIN}-1$. Table 2 summarises the grade of protection conferred by AdSOD towards SIN-1 in human islets $(69.9 \pm 10.5 \%$ protection at $200 \mu \mathrm{mol} / 1$ and $40.5 \pm 8.9 \%$ protection at $400 \mu \mathrm{mol} / \mathrm{l})$ and INS-1 cells $(82.2 \pm 8.8 \%$ protection at $200 \mu \mathrm{mol} / \mathrm{l}$ and $31.1 \pm 5.8 \%$ protection at $400 \mu \mathrm{mol} / \mathrm{l})$. At higher doses of SIN-1 the grade of protection was reduced, especially in INS-1 cells (Table 2). Additional experiments $(n=3)$ were conducted on INS-1 cells with SNAP, a pure nitric oxide donor. As illustrated in Fig. 3, a dose-dependent cytotoxic effect of SNAP was observed on control cells: $22.7 \pm 5.7 \%$, $31.7 \pm 6.8 \%, 44.7 \pm 9.5 \%$ cytotoxicity at $350 \mu \mathrm{mol} / \mathrm{l}$, $500 \mu \mathrm{mol} / \mathrm{l}$ and $750 \mu \mathrm{mol} / \mathrm{l}$, respectively. Transfection of cells with AdSOD at MOI 10:1 conferred a reduction of cytotoxicity: $10.7 \pm 4.1 \%, 17.0 \pm 4.4 \%$, $29.7 \pm 4.4 \%$ cytotoxicity, which did not reach statistical significance. The higher MOI (20:1) resulted in significantly higher protection than MOI 10:1: $1.7 \pm 1.2 \%, \quad 5.4 \pm 1.9 \%, \quad 17.1 \pm 9.7 \%$ cytotoxicity $(p<0.05$ AdSOD vs control at 350 and $500 \mu \mathrm{mol} / \mathrm{l}$, $p=\mathrm{NS}$ at $750 \mu \mathrm{mol} / \mathrm{l})$. Control experiments were conducted with a similar adenoviral vector containing no cDNA (AdNull) and did not show any reduction of SIN-1 or SNAP-induced cytotoxicity (data not shown).

Effects of SOD gene transfer on islet functionality. The endocrine function of human islets, aliquoted in four groups (control and AdSOD-transfected, with or without stress), was tested by static incubations 24 to $72 \mathrm{~h}$ after the induction of oxidative stress by

Table 2. Effect of SOD gene transfer on human islet and INS-1 cell viability

\begin{tabular}{|c|c|c|c|c|c|c|}
\hline \multirow{3}{*}{$\begin{array}{l}\text { Dose of } \\
\text { SIN-1 }\end{array}$} & \multicolumn{3}{|c|}{ INS-1 cells ${ }^{\mathrm{c}}$} & \multicolumn{3}{|c|}{ Human islets $^{\mathrm{c}}$} \\
\hline & \multicolumn{2}{|c|}{$\%$ cytotoxicity } & \multirow{2}{*}{$\begin{array}{l}\% \\
\text { protection }^{\mathrm{b}}\end{array}$} & \multicolumn{2}{|c|}{$\%$ cytotoxicity } & \multirow{2}{*}{$\begin{array}{l}\% \\
\text { protection }\end{array}$} \\
\hline & Control & AdSOD & & Control & AdSOD & \\
\hline $400 \mu \mathrm{mol} / 1$ & $27.2 \pm 2.2$ & $18.5 \pm 1.4^{\mathrm{d}}$ & $31.1 \pm 5.9$ & $32.6 \pm 2.7$ & $19.2 \pm 2.2^{\mathrm{d}}$ & $40.5 \pm 8.9$ \\
\hline $800 \mu \mathrm{mol} / 1$ & $61.9 \pm 3.6$ & $58.6 \pm 1.1$ & $5.0 \pm 3.6$ & $44.5 \pm 1.5$ & $35.9 \pm 1.4^{\mathrm{d}}$ & $18.9 \pm 2.3$ \\
\hline
\end{tabular}

${ }^{\text {a }}$ Islets or INS-1 cells were transfected by AdSOD at an MOI of $10: 1,72 \mathrm{~h}$ before SIN-1 cytotoxic challenge.

${ }^{\mathrm{b}}$ Protection rate was computed as $(\mathrm{C}-\mathrm{T} / \mathrm{C}) \times 100$, where $\mathrm{C}$ and $\mathrm{T}$ were cytotoxicity observed in control and transfected cells, respectively.

${ }^{\mathrm{c}}$ Data were pooled from three different INS-1 cell or islet preparations.

${ }^{\mathrm{d}} p<0.05$ AdSOD vs control. Cytotoxicity levels were compared by analysis of variance completed by Tukey-Kramer's test. Data are means \pm SEM 


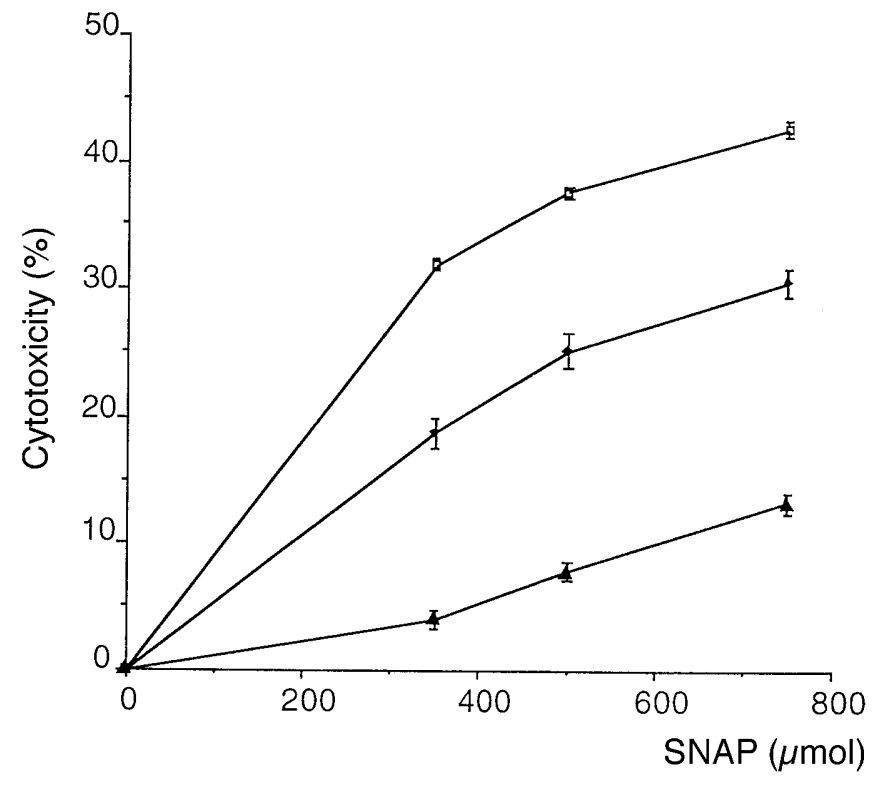

Fig. 3. Reduction of SNAP-induced cytotoxicity on INS-1 cells by AdSOD

INS- 1 cells were transfected at MOI: 10 or MOI: 20 , incubated at $3 \times 10^{4}$ cells per well for $72 \mathrm{~h}$, stressed by increasing doses of SNAP, and assessed for viability by WST-1 assay $16 \mathrm{~h}$ later. Data show means \pm SEM (12 wells per experimental group) of a representative experiment. $\square \square-$ Control, $\neg$ AdSOD 10:1, \ AdSOD 20:1

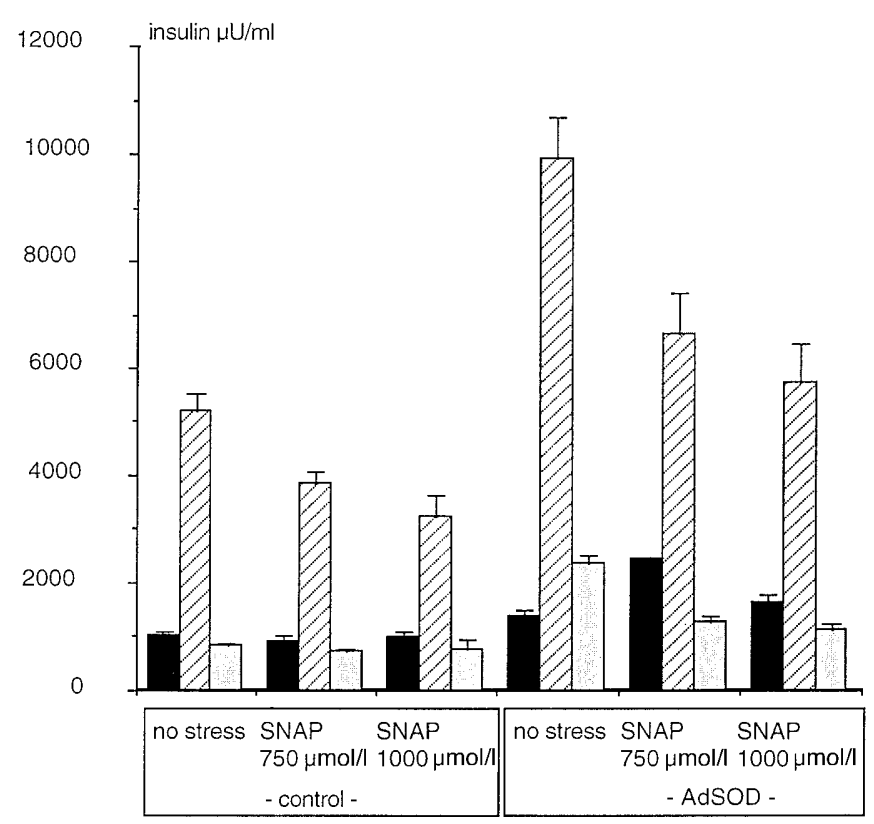

Fig. 4. AdSOD increases basal-insulin and stimulated-insulin release, both in basal situation or after a SNAP stress

Human islets were infected with AdSOD (MOI 25), exposed $72 \mathrm{~h}$ later to oxidant stress (SNAP), and were successively incubated in basal (glucose $3.3 \mathrm{mmol} / \mathrm{l}$ ), stimulation (glucose $27.5 \mathrm{mmol} / \mathrm{l}+$ theophylline $10 \mathrm{mmol} / \mathrm{l}$ ), then basal medium again for three 1 -h periods, $72 \mathrm{~h}$ after stress. A typical static incubation is shown here and was repeated on three human islet preparations. Basal medium, $\mathbb{Z}$ Stimulation medium, $\square$ Basal medium
$1000 \mu \mathrm{mol} / \mathrm{l}$ SNAP $(n=3)$. Control islets released insulin upon a glucose-theophylline stimulation (baseline $1099 \pm 87$, stimulated $3929 \pm 427 \mu \mathrm{U} / \mathrm{h} / 100$ islets). AdSOD transfected islets released more insulin than control islets in basal conditions $(1313 \pm 76, p=\mathrm{NS}$ vs control), as well as in stimulated conditions $(6098 \pm 668, p<0.05$ vs control). Upon SNAP exposure, insulin release was significantly lower in control islets than in AdSOD transfected islets, both in basal conditions (965 \pm 92 vs $1473 \pm 93, p<0.05$ vs control) and in stimulated conditions $(2068 \pm 276$ vs $3368 \pm 410, p<0.05$ vs control). Insulin content was significantly increased in AdSOD-transfected islets $(19671 \pm 1337 \mu \mathrm{U} / \mathrm{ml})$ compared to control islets $(10567 \pm 571 \mu \mathrm{U} / \mathrm{ml}, p<0.05)$. In additional experiments $(n=3)$, AdNull transfected islets did not behave differently than control islets before stress (baseline $722 \pm 85$ vs $893 \pm 146$; stimulated $2003 \pm 202$ vs $2289 \pm 201$; $p=$ NS) or after SNAP exposure (baseline $592 \pm 69$ vs $655 \pm 93$; stimulated $1564 \pm 139$ vs $1602 \pm 141 ; p=\mathrm{NS}$ ) and had similar insulin contents under non-stressed conditions $(20195 \pm 1476$ vs $22470 \pm 1440, p=\mathrm{NS})$. Data from a representative experiment using increasing doses of SNAP are shown in Fig. 4.

\section{Discussion}

In our study we established that it is possible to overexpress $\mathrm{Cu} / \mathrm{ZnSOD}$ in human islets in vitro, using a simple adenoviral transfection procedure, and thereby to reduce the cytotoxic effects induced by nitric oxide donors.

Our results could have implications in future islet transplantation procedures. If nitric oxide is indeed a candidate mediator of pancreatic beta-cell damage in autoimmune diabetes mellitus, it is also implicated in islet allotransplantation failure as well [22-23]. Intrahepatic NO production is related to the islet mass transplanted. Nitric oxide production is higher in recipients of allogeneic rather than syngeneic islets. Inhibiting NO production in the minimal islet transplant model decreased the delay of islet function. Nitric oxide is produced by the enzyme nitric oxide synthase (NOS), whose inducible form (iNOS) can be modulated by cytokines in rodent and human pancreatic islets [24-25]. Cytokines released by activated mononuclear cells can induce a stress gene response which appears to be restricted to beta cells and is not observed in alpha cells [26]. Genes responding to cytokine exposure include iNOS and MnSOD [27].

Several strategies have been proposed to reduce islet inflammation and nitric oxide cytotoxicity. These include giving several inducible nitric oxide synthase inhibitors, the suppression of poly-(ADP-ribose)-polymerase, the use of interleukin-12 antagonist, or the induction of endogenous stress proteins 
[28]. The gene transfer procedure, such as the adenoviral vector used in our study, offers the main advantage of being easily applied to cultured islets in vitro and of being restricted to islets without adverse systemic effects. Therefore it has great potential implications in islet transplantation. In addition, the level of SOD overexpression reached in our work in human islets (twofold to threefold increase) is comparable to those achieved in other studies with transgenic approaches in cells lines $[9,29]$. The pattern of transgene distribution observed is noteworthy when whole islets were transfected with a reporter gene as one third of islet cells actually expressed the neogene, as in previous studies [30-32]. A higher efficiency of transfection and a better distribution of the transgene within the core of the islets could be expected with more recent vectors, namely lentiviral vectors, which could be interesting to test in our model.

Controversial observations were reported regarding SOD overexpression effects on beta cells. Transgenic strains of mice overexpressing $\mathrm{Cu} / \mathrm{ZnSOD}$ transgene in their beta-cells showed an enhanced resistance to alloxan-induced or streptozotocin-induced diabetes [9-10]. Stable overexpression of MnSOD in INS-1 cells provided a complete protection against IL-1 beta-mediated cytotoxicity, an effect that seemed correlated with a sharp reduction in IL-1 beta-induced nitric oxide production [11]. On the other hand, data recently established in RINm5F cells showed a complementary effect of catalase plus SOD or catalase plus glutathione peroxidase on hydrogen peroxide cytotoxicity [12]. In these cells, however, as opposed to single overexpression of catalase or glutathione peroxidase, single overexpression of SOD either had no effect on the toxicity of hydrogen peroxide or increased it [13]. More recently, RINm5F cells stably overexpressing $\mathrm{Cu} / \mathrm{ZnSOD}$ were shown to be protected against the toxicity of SNAP and SIN-1 [29]. Using an adenoviral vector system, our data confirms the latter findings on another beta-cell line and established that primary human islets can also benefit from the same procedure. We also observed an improvement in unstressed transfected islet insulin secretory capacities under both basal and stimulated conditions that persisted after application of stress. If, however, the absolute insulin secretion was enhanced in transfected islets, a similar one-third reduction of insulin secretion was observed after application of stress in both control and transfected islets thus questioning the nature and reality of the protection conferred by AdSOD. A modification in mitochondrial metabolism induced by SOD overexpression could contribute to the increase in insulin secretion, as increasing evidence outlines the pivotal role of mitochondria in insulin secretion [33]. Overexpression of SOD could raise the threshold for oxidative damage leading to insulin secretion deterioration, that could already be present in usual culture conditions. The relatively low transgene expression in whole islets could be insufficient to counteract additional stress. Alternatively, the increase in insulin content observed in transfected islets could reflect a better survival of these islets in culture, i. e. AdSOD could reduce the extent of islet mass decrease usually observed in culture and improve islet survival in culture. Further experiments are needed to clarify these points.

The exquisite sensitivity of islet beta cells to oxidative stress was linked to the low expression of antioxidant genes in islets, as compared to other tissues [6-7]. It is noteworthy that human islets express higher SOD or catalase activity than rodent or porcine islets [14]. It can be speculated that this plays a part in the differential susceptibility of human and rodent islets to cytokine cytotoxicity. A similar susceptibility to an in vitro pharmacological stress does not rule out a differential sensitivity to in vivo physiological or pathophysiological oxidative stress. Still, both human and rat-derived INS-1 cells gain a significant protection by SOD transfection as it was already shown with catalase, meaning that shifting the defense systems may be sufficient. This study strengthens our previous work in which we established that adenoviral-driven catalase overexpression reduced the cytotoxicity of superoxide donors on human, porcine and rat islets [14]. Thus, adenoviral transfection of catalase and $\mathrm{Cu} / \mathrm{ZnSOD}$ possibly has synergistic effects.

Although similar observations were made with SIN-1 and SNAP in our study, a trend towards a higher protection of AdSOD appeared with SNAP. The difference between SIN-1 and SNAP is their mechanism of NO production. Superoxide and NO are generated at similar rates as SIN-1 spontaneously decomposes, that will rapidly react together to form peroxynitrite. SNAP spontaneously dissociates to $\mathrm{NO}$ and the thiyl radical, the latter secondarily generating superoxide [34]. Peroxynitrite is a highly reactive oxidant species produced by the reaction of the free radicals superoxide and nitric oxide. Recent studies have established that peroxynitrite was generated in beta cells of NOD mice and human islets and contributed to their destruction [3,35]. More recently a synergistic toxicity of NO donors and oxygen free radicals on a beta-cell line was established, that could be efficiently reduced by overexpressing catalase, glutathione peroxidase or $\mathrm{Cu} / \mathrm{ZnSOD}$ [29]. This further favours the use of synergistic antioxidant enzymes in future islet studies.

In summary, our study established that adenovirus-mediated SOD gene transfer can significantly raise SOD expressions in human islets for prolonged periods. This procedure allowed a clear reduction of islet susceptibility to nitric oxide donors and an improvement of insulin secretory capacities in vitro. This approach could be helpful in reducing nonspecific inflammation and promoting islet engraftment in future transplantation trials. 
Acknowledgements. We thank Mrs M. Bayle for doing the insulin radioimmunassay. This work was supported by grants from Fondation de France, Institut Electricite Sante and DRC Grenoble. Human Islet Isolation program is supported by grants from University Hospital of Lille, Etablissement Français des Greffes, and INSERM.

\section{References}

1. Rabinovitch A, Suarez-Pinzon WL, Strynadka K, Lakey JRT, Rajotte RV (1996) Human pancreatic islet $\beta$-cell destruction by cytokines involves oxygen free radicals and aldehyde production. J Clin Endocrinol Metab 81: 3197-3202

2. Corbett JA, Sweetland MA, Wang JL, Lancaster JR Jr, McDaniel ML (1993) Nitric oxide mediates cytokine-induced inhibition of insulin secretion by human islets of Langerhans. Proc Natl Acad Sci USA 90: 1731-1735

3. Suarez-Pinzon WL, Szabó C, Rabinovitch A (1997) Development of autoimmune diabetes in NOD mice is associated with the formation of peroxynitrite in pancreatic islet $\beta$-cells. Diabetes 46: 907-911

4. Horio F, Fukuda M, Katoh H et al. (1997) Reactive oxygen intermediates in autoimmune islet cell destruction of the NOD mouse induced by peritoneal exudate cells (rich in macrophages) but not T cells. Diabetologia 37: 22-31

5. Brenner HH, Burkart V, Rothe H, Kolb H (1993) Oxygen radical production is increased in macrophages from diabetes prone BB rats. Autoimmunity 15: 93-98

6. Lenzen S, Drinkgern J, Tiedge M (1996) Low antioxidant enzyme gene expression in pancreatic islets compared with various other mouse tissues. Free Radic Biol Med 20: 463-466

7. Welsh N, Margulis B, Borg LA et al. (1995) Differences in the expression of heat-shock proteins and antioxidant enzymes between human and rodent pancreatic islets: implications for the pathogenesis of insulin-dependent diabetes mellitus. Mol Med 1: $806-820$

8. Eizirik DL (1996) Beta-cell defence and repair mechanisms in human pancreatic islets. Horm Metab Res 28: 302-305

9. Kubisch HM, Wang J, Luche R et al. (1994) Transgenic copper/ zinc superoxide dismutase modulates susceptibility to type I diabetes. Proc Natl Acad Sci USA 91: 9956-9959

10. Kubisch HM, Wang J, Bray TM, Phillips JP (1997) Targeted overexpression of $\mathrm{Cu} / \mathrm{Zn}$ superoxide dismutase protects pancreatic beta-cells against oxidative stress. Diabetes 46: $1563-1566$

11. Hohmeier HE, Thigpen A, Tran VV, Davis R, Newgard CB (1998) Stable expression of manganese superoxide dismutase (MnSOD) in insulinoma cells prevents IL-1beta-induced cytotoxicity and reduces nitric oxide production. J Clin Invest 101: 1811-1820

12. Tiedge M, Lortz S, Drinkgern J, Lenzen S (1997) Relation between antioxidant enzyme gene expression and antioxidative defense status of insulin-producing cells. Diabetes 46: $1733-1742$

13. Tiedge M, Lortz S, Munday R, Lenzen S (1998) Complementary action of antioxidant enzymes in the protection of bioengineered insulin-producing RINm5F cells against the toxicity of reactive oxygen species. Diabetes 47: 1578-1585

14. Benhamou PY, Moriscot C, Richard MJ et al. (1998) Adenovirus-mediated catalase gene transfer reduces oxidant stress in human, porcine and rat pancreatic islets. Diabetologia 41: $1093-1100$

15. Kerr-Conte JA, Pattou F, Lecomte-Houcke M et al. (1996) Ductal cyst formation in collagen-embedded adult human islet preparations: a means to the reproduction of nesidioblastosis in vitro. Diabetes 45: $1108-1114$

16. Asfari M, Janjic D, Meda P, Li G, Halban PA, Wollheim CB (1992) Establishment of 2-mercaptoethanol-dependent differ- entiated insulin-secreting cell lines. Endocrinology 130: $167-178$

17. Danel C, Erzurum SC, Prayssac P et al. (1998) Gene therapy for oxidant injury related diseases: adenovirus-mediated transfer of superoxide dismutase and catalase cDNAs protects against hyperoxia but not against ischemia-reperfusion lung injury. Hum Gene Ther 9: 1487-1496

18. Marklund S, Marklund G (1974) Involvement of the superoxide anion radical in the autooxidation of pyrogallol and a convenient assay of superoxide dismutase. Eur J Biochem 47: 469-474

19. Peakman M, McNab GL, Heaton ND, Tan KC, Vergani D (1994) Development of techniques for obtaining monodispersed human islet cells. Transplantation 57: 384-393

20. Eizirik DL, Delaney CA, Green MH et al. (1996) Nitric oxide donors decrease the function and survival of human pancreatic islets. Mol Cell Endocrinol 118: 71-83

21. Janjic D, Wollheim CB (1992) Islet cell metabolism is reflected by the MTT (tetrazolium) colorimetric assay. Diabetologia 35: 482-485

22. Xenos ES, Stevens RB, Sutherland DE et al. (1994) The role of nitric oxide in IL- $\beta$-mediated dysfunction of rodent islets of Langerhans. Implications for the function of intrahepatic islet grafts. Transplantation 57: 1208-1212

23. Stevens RB, Ansite JD, Lokeh A, Rossini TJ, Mills CD, Sutherland DE (1995) Expression of intrahepatic inducible nitric oxide synthetase mRNA correlates with production of nitric oxide during intraportal isogeneic and allogeneic rat islet transplantation. Transplant Proc 27: 615-616

24. Rabinovitch A (1998) An update on cytokines in the pathogenesis of insulin-dependent diabetes mellitus. Diabetes Metab Rev 14: 129-151

25. Eizirik DL, Pavlovic D (1997) Is there a role for nitric oxide in beta-cell dysfunction and damage in IDDM? Diabetes Metab Rev 13: 293-307

26. Strandell E, Buschard K, Saldeen J, Welsh N (1995) Interleukin-1 beta induces the expression of hsp70, heme oxygenase and Mn-SOD in FACS-purified rat islet beta-cells, but not in alpha-cells. Immunol Lett 48: 145-148

27. Eizirik DL, Flodström M, Karlsen AE, Welsh N (1996) The harmony of the spheres: inducible nitric oxide synthase and related genes in pancreatic $\beta$ cells. Diabetologia 39: 875-890

28. Rothe H, Kolb H (1999) Strategies of protection from nitric oxide toxicity in islet inflammation. J Mol Med 77: 40-44

29. Tiedge M, Lortz S, Munday R, Lenzen S (1999) Protection against the co-operative toxicity of nitric oxide and oxygen free radicals by overexpression of antioxidant enzymes in bioengineered insulin-producing RINm5F cells. Diabetologia 42: 849-855

30. Csete ME, Benhamou PY, Drazan KE et al. (1995) Efficient gene transfer to pancreatic islets mediated by adenoviral vectors. Transplantation 59: 263-268

31. Sigalla J, David A, Anegon I et al. (1997) Adenovirus-mediated gene transfer into isolated mouse adult pancreatic islets: normal beta-cell function despite induction of an anti-adenovirus immune response. Hum Gene Ther 8: 1625-1634

32. Leibowitz G, Beattie GM, Kafri T et al. (1999) Gene transfer to human pancreatic endocrine cells using viral vectors. Diabetes 48: 745-753

33. Maechler P, Jornot L, Wollheim CB (1999) Hydrogen peroxide alters mitochondrial activation and insulin secretion in pancreatic beta cells. J Biol Chem 274: 27905-27913

34. Feelisch M, Stamler JS (1996) Donors of nitrogen oxides. In: Methods in Nitric Oxide Research. Wiley, New York, pp 71-115

35. Delaney CA, Tyrberg B, Bouwens L, Vaghef H, Hellman B, Eizirik DL (1996) Sensitivity of human pancreatic islets to peroxynitrite-induced cell dysfunction and death. FEBS Lett 394: 300-306 